\title{
Woodland Hills v. City Council of Los Angeles: Electoral Politics and Quasi-Judicial Fairness
}

In Woodland Hills Residents Association, Inc. v. City Council,' the California Supreme Court faced the issue of whether "the mother's milk of politics"2-money, here in the form of campaign contributions-might constitute an improper influence on quasi-judicial decisionmaking. The court found that citizens challenging a land development permit application were not denied a fair hearmg when they appeared before a city council wliose members had received campaign contributions from the developer who sought the application. Moreover, the court declined to review any standard of fairness that would interfere with the system of private campaign financing, and, ultimately, the first amendment rights of contributors.

The Woodland Hills case arose from the attempts of the Woodland Hills Residents Association to block a development in its community by challenging the city's approval of the project. The association claimed that procedural defects invalidated the approval. In addition, the association claimed that it did not receive a fair hearing before the city council because several of the council members who voted for approval of the development had received substantial campaign contributions from the developer and related parties. It asked the court to disqualify those council members from voting on any subsequent action involving the development. The supreme court affirmed the judgment of the trial court-accepting the association's principal procedural claim - but rejected the disqualification argument.

The justices were unanimous in their judgment, but filed a total of four separate opimions, due to their disagreennent over the issue of the campaign contributions. Justice Clark, writing for the court, held that the liearing afforded the association met statutory requireinents. He intimated that any standard mandating disqualification of officials in like instances due to their receipt of campaign contributions would unconstitutionally burden the contributors' rights to pohitical speech. The three concurring justices, led by Chief Justice Bird, accepted the majority's statutory analysis but suggested that the legislature should be able to draft "appropriately defined" legislation to deal with the threat of

1. 26 Cal. 3d 938, 609 P.2d 1029, 164 Cal. Rptr. 255 (1980). (Clark, J.)

2. Id. at 953, 609 P.2d at 1037, 164 Cal. Rptr. at 264 (Newman, J., concurring). 
improper influence posed by unrestricted campaign contributions, without infringing the first amendment.

This Note argues that while the court correctly concluded that disqualification was not mandated by the Political Reform Act, it failed to otherwise consider whether campaign contributions prevented the association from liaving a fair liearing. The court was not constitutionally barred from settimg or applying standards of fairness in this area, because a limited restriction on the political speech of contributors would not necessarily have violated the first amendment. First amendment considerations do, however, impose strict limits on the scope and nature of any law that would be drafted. This Note then argues that as a matter of policy, neither the courts nor the legislature should impose a disqualification standard based on receipt of campaign contributions. While sucl contributions umght threaten to corrupt quasi-judicial decisionmaking, the problem is not limited to the influence of contributions on a decisionmaking process that resembles adjudication. Rather, the problem of potentially tainted influences sliould be treated uniformly, without regard to low the affected process is characterized.

Section I of this Note discusses the history of the Woodland Hills controversy, ${ }^{3}$ the issues presented to the supreme court, and the court's disposition of those issues. Section II analyzes the constitutionality of a disqualification standard for contribution recipients actimg as quasi-judicial officers. Part III examines the court's fair liearing holding and notes the limitations of the Political Reform Act in ensuring fairness. It further considers the wisdom of creating judicial or legislative standards for fairness and the appearance of fairness ${ }^{4}$ for a process that is

3. The case is the third in a series of cases based on the same underlying controversy. The first Woodland Hills litigation involved the Los Angeles City Council's original action on the subdivision approval. 44 Cal. App. 3d 825, 118 Cal. Rptr. 856 (2d Dist. 1975). The next Woodland Hills case reached the California Supreine Court. At issue was the awarding of plaintiffs attorney fees in the first case. 23 Cal. 3d 917, 593 P.2d 200, 154 Cal. Rptr. 503 (1979).

4. An appearauce of fairness doctrine is grounded in the notion that circumstances constituting a probability of bias on the part of a decisioninaker are sufficient to inandate disqualification, in the absence of any proof of actual bias:

Such a stringent rule may sometimes bar trial by judges who have no actual bias and who would do their very best to weigh the scales of justice equally between contending parties. But to perforin its high function in the best way "justice must satisfy the appearance of justice."

In re Murchison, 349 U.S. 133, 136 (1955) (quoting Offutt v. United States, 348 U.S. 11, 14 (1954)). While fairness itself is an essential component of the decisionmaking process, guaranteeing the appearance of fairness assures the faith of contestants and the general public in that system.

The appearance of fairness doctrine denotes the application of the standard to a particular set of circumstances by a neutral decisionmaker. In a sense, the provisions of the California Political Reforin Act, CAL. Gov'T CoDE $\S \S 81000-91014$ (West 1976 \& Supp. 1981), are a codification of the appearance of fairness doctrine which has replaced case-by-case determination by specifying circumstances that are deeined to present an appearance of unfairness. See notes 19-24 and accompanying text infra. 
inherently political, albeit quasi-judicial.

I

\section{CASE History AND Decision}

The Woodland Hills controversy began when the original developer, Consolidated Resources, Inc., filed an application for the approval of a tentative tract map with the advisory agency of the city of Los Angeles on June 13, 1972. The developer proposed substantial gradimg and filling on steep hillside land in order to construct 123 new homes. ${ }^{5}$ After preliminary approval by the city's advisory agency and the city planning commission, the Los Angeles City Council, in a tie vote, upheld the approval of the project.

The Woodland Hills Residents Association unsuccessfully challenged the project's approval in Los Angeles Superior Court. It then appealed that adverse decision. The court of appeal vacated the map approval, because of the city's failure to make findings consistent with the area's general plan. ${ }^{6}$ The court remanded the case to the trial court, which in turn issued a peremptory writ requiring the city council to reconsider the application.

Under the authority of the writ, the city chose to expedite the reconsideration process by bypassing the advisory agency and planning commission. ${ }^{7}$ The city prepared two separate Environmental Impact Reports (EIR's), one on the original 123 unit proposal and another on a 73 unit alternative submitted by California Western Concepts, the orig-

5. 44 Cal. App. 3d at 827,118 Cal. Rptr. at 856 .

6. Id. at $838,118 \mathrm{Cal}$. Rptr. at 864 . The appellate court held that "[a] tie vote . . where ... a finding of consistency was a legal prerequisitc of approval, did not constitute approval action.... The trial court erred in determining that there was a finding by implication which was sufficient for approval of the proposed subdivision map." Id.

The court of appeal decision was thus unclear as to whether the action of the city council should have been invahdated because the tic vote of the council did not suffice for an implied finding or because even approval by a majority vote would not suffice when the applicable statute called for findings. The lack of specificity is attributable to the court's reliance on the rule set forth by the California Supreme Court in Topanga Ass'n For A Scenic Community v. City of Los Angeles, 11 Cal. 3d 506, 522 P.2d 12, 113 Cal. Rptr. 836 (1974). Topanga held that in variance proceedings, regardless of statutory directive, the deciding body could not rely on implied findings. Rather, it inust "render findings sufficient both to enable the parties to determine whether and on what basis they should seek review and, in the event of review, to apprise a reviewing court of the basis for the . . . action." Id. at 514, 522 P.2d at 16,113 Cal. Rptr. at 840 . Since the action by the city council would, at best, have constituted an implied finding, it could not be valid under Topanga, regardless of whether a tie vote was "deemed" approval or a majority actually gave approval. The appellate court instructed the trial court to send the matter back to the city council for the council to make findings that would enable a reviewing court to "bridge the analytical gap between the evidence and the ultimate decision of the council," consistent with Topanga. $44 \mathrm{Cal}$. App. 3d at 838, 118 Cal. Rptr. at 863.

7. 26 Cal. 3d at 947,609 P.2d at 1034, 164 Cal. Rptr. at 260. 
inal developer's successor. ${ }^{8}$ On April 19, 1977, the Los Angeles City Council approved the 123 unit proposal. ${ }^{9}$

These actions of the city council took place against a backdrop of apparently orchestrated campaign contributions made by California Western Concepts, its attorneys, and its engineering consultants. These contributions amounted to some $\$ 10,000$, and were made in the time period between the trial court's issuance of the peremptory writ and the second vote by the city council. ${ }^{10}$ Approximately eighty percent of the funds went to the campaign committees of the council members who ultimately voted to approve the developer's proposal. ${ }^{11}$ In addition to the quantitative distribution of the contributions, the timing and amounts of the various gifts created an appearance of coordination between the donors. ${ }^{12}$

The association again challenged the council's action in superior court. It charged that the council failed to comply with the California Environmental Quality Act (CEQA) ${ }^{13}$ by preparing two separate EIR's and by neglecting to submit the reports for public discussion. The court found that the council had indeed acted improperly, and issued a suppleinental writ requiring the city to prepare a single integrated EIR and submit it to public discussion. ${ }^{14}$

The city council appealed from the judgment of the superior court. This in turn hastened the association's concurrent appeal, which argued that the trial court improperly rejected the association's contention that

8. Id. at 949,609 P.2d at 1035,164 Cal. Rptr. at 261 .

9. 153 Cal. Rptr. 651, 658 (App., 2d Dist. 1979) (pursuant to CAL. R. CT. 976 the official report was automatically depublished when California Supreme Court heard the case).

10. Id. at 657 .

11. See Brief for Residents Association at 23, Woodland Hills Residents Ass'n v. City Council, 26 Cal. 3d 938, 609 P.2d 1029, 164 Cal. Rptr. 255 (1980) (\$8,000 went to members of the majority). Three council members who voted against the approval received "nominal gifts." Id.

Illustrative of the pattern of contributions were those made to Councilman Donald Lorenzen. Lorenzen received a $\$ 500$ contribution from the developer two days after the council had voted unanimously to resolve an inconsistency between the area map and the area plan in a manner unfavorable to the developer, $\$ 250$ was contributed six days later by Latham \& Watkins, the developer's law firm. During a nine-day period the following month, the consultants, Spindler Engimeering Corp., contributed \$250, and Latham \& Watkins and the developer each gave another $\$ 125$. The contributions continued during the month following the April 1977 vote of approval, with $\$ 250$ coming from both the law firn and the consultants. All told, Councilman Lorenzen received contributions from these parties of $\$ 1,750$ during a 90-day period. $153 \mathrm{Cal}$. Rptr. at 657.

12. For example, on consecutive days in October 1975, first the law firn and then the consultants contributed the same sum $-\$ 120-$ to Councilman Robert Wilkinson. The consultants gave $\$ 500$ to the campaign committee of John S. Gibson, Jr. on January 17, 1977; the next day the law firn gave the committee $\$ 250$. Additional $\$ 100$ contributions were made to the Gibson campaign by the same parties on May 11 and May 17, 1977. 153 Cal. Rptr. at 657.

13. CAL. Pub. Res. COdE $\$ \S 21000-21176$ (West 1977 \& Supp. 1981).

14. $26 \mathrm{Cal} .3 \mathrm{~d}$ at 944,609 P.2d at $1031,164 \mathrm{Cal}$. Rptr. at 258. 
it had been denied the fair hearing to which it was statutorily entitled. ${ }^{15}$ The association argued that particular council members should have been disqualified from voting on the proposed subdivision because the developer and its agents and representatives had made pohtical contributions to the campaign committees of these council menibers. ${ }^{16} \mathrm{Be}$ cause these council members were not disqualified, the association claimed it was deprived of a fair hearing.

The suprenie court affirmed ${ }^{17}$ the trial court's finding of procedural defects in the action of the city council, with Justice Clark writing the opinion for the court. As to the fair hearing issue, the court held that the trial court had correctly rejected the association's contention that the campaign contributions by the developer and its representatives prevented the residents from receiving a fair hearing within the meaning of California Code of Civil Procedure section 1094.5. ${ }^{18}$

The court noted that campaign contributions are regulated in California by the Political Reform Act of $1974^{19}$ and relevant portions of the state election code. ${ }^{20}$ With respect to contributions, these statutory schema are oriented toward the disclosure, and not the prohibition, of campaign contributions. ${ }^{21}$ While the Political Reform Act does im fact require elected officials to disqualify themselves from participating in any decision in which they have a financial interest, the Act expressly

15. Cal. Civ. Proc. Code $\S 1094.5$ (West 1980).

16. 26 Cal. 3d at 944, 609 P.2d at 1031-32, 164 Cal. Rptr. at 258.

17. The court of appeal had affirmed the action of the trial court in issuing the supplemental peremptory writ, but added an additional ground:

The findings of fact set forth above mandate as a conclusion of law that petitioners

... were denied a fair trial within the meaning of Code of Civil Procedure section

1094.5. . . . [R]espondent City Council . . . cannot be deemed an impartial tribunal by

virtue of the contributions to the campaign committees . . . made by California Western

Concepts . . . and its agents.

153 Cal. Rptr. at 658.

The appellate court instructed the trial court to modify the writ of mandamus to provide "that any action taken by the City Council shall not be taken as a result of votes for such action by members of the City Council whose campaign committees received contributions from real party in interest, its engineering consulting finn, or its attorneys ...." Id. at 661 .

18. 26 Cal. 3d at 945, 609 P.2d at 1032, 164 Cal. Rptr. at 259.

19. CAL. Gov't CODE $\$ \$ 81000-91014$ (West 1976 \& Supp. 1981).

20. Waxinan-Dymally Campaign Disclosure Act, CAL. ELEC. CODE $\$ \S 11500-11622$ (West 1977 \& Supp. 1980). Some provisions of the Act were repealed and placed in the Political Reform Act by the 1974 referendum; others were repealed and replaced by substitute ineasures in the Pohitical Reform Act.

21. The concern of both acts is disclosure of contributions, not their himitation or prohibition. The contribution prohibitions that are contained in the Political Reform Act, CAL. Gov'T CODE $\$ \S 84300-84307$ (West 1976 \& Supp. 1980), deal with attcmpts to evade disclosure by use of such devices as cash contributions, intermediaries, and surreptitious mass mailings on behalf of candidates. Thus, the Act's regulation of contributions prohibits only in order to facilitate disclosure. The conflict of interest sections, CAL. Gov'T CODE $\$ \$ 87100-87313$ (West 1976 \& Supp. 1980), on the other hand, mandate disclosure in order to facilitate the basic prohibition against advancing one's personal interest in a governinental capacity. 
excludes campaign contributions from the category of financial imterests. $^{22}$ Under such a statutory scheme, the court concluded, when contributions are given in accordance with the law, as they were in Woodland Hills, there is no reason to beheve that the contributions demonstrate undue bias or prevent a fair hearing. ${ }^{23}$ The majority, moreover, stated that the Pohtical Reforn Act and complementary criminal sanctions provided "[a]dequate protection against corruption and bias." 24 The court thus refused to require the disquahification of the council members froin any future action on the application of the developer.

In writing for the court, Justice Clark further observed that cainpaign contributions involve the exercise of a fundamental first annendment right protected by the Cahfornia and United States Constitutions. Disqualifying recipients from voting on matters concerning the contributor would impermissibly burden the constitutionally protected rights of pohtical speech and association. Justice Clark thus cast doubt on the ability of a legislative body to mandate disqualification of a contribution recipient by noting that governinental restraint on political contributions would be justified only by a compelling state interest. ${ }^{25}$

All the members of the court concurred in the majority's finding of procedural defects and in its rejection of the association's fair hearing claim. ${ }^{26}$ In examining the issue of the campaign contributions, however, Chief Justice Bird and Justices Newman and Tobriner adopted a much narrower holding. While they agreed with Clark that the receipt of contributions would not disqualify a decisionmaker under the principles of section 1094.5, they sought to temper Justice Clark's sweeping constitutional statements as to the inviolability of pohtical contributions. The concurring justices argued that some infringement of the right to contribute to campaigns is constitutionally acceptable and that the threat of corrupt influences on the adjudication process is worthy of remedial action. ${ }^{27}$ The concurring justices moreover agreed that the adequacy of the Pohtical Reforn Act is not a inatter for the court to

22. 26 Cal. 3d at 945-46, 609 P.2d at 1032-33, 164 Cal. Rptr. at 259 (citing CAL. Gov'T CoDE $\S 82030$ (West Supp. 1980)).

23. Id. at 947,609 P.2d at 1033,164 Cal. Rptr. at 260 ; Id. at 953,609 P.2d at 1037,164 Cal. Rptr. at 264 (Tobriner, J., concurring).

24. Id. at 947,609 P.2d at 1033, 164 Cal. Rptr. at 260 .

25. Id. at 946,609 P.2d at 1033, 164 Cal. Rptr. at 260 .

26. Id. at 944,609 P.2d at 1032, 164 Cal. Rptr. at 258; Id. at 950-51, 609 P.2d at 1036, 164 Cal. Rptr. at 262 (Bird, C.J., concurring and dissenting); Id. at 952, 609 P.2d at 1037, 164 Cal. Rptr. at 264 (Newman, J., concurring). Justice Tobriner, who joined the majority opinion, wrote a separate opmion echoing the concerns of the Chief Justice and Justice Newinan. Id. at 953, 609 P.2d at 1037, 164 Cal. Rptr. at 264.

27. Id. at 951,609 P.2d at 1036, 164 Cal. Rptr. at 262-63 (Bird, C.J., concurring and dissenting). 
determine; it is for the legislature to decide whether current protections are adequate, and to define standards to apply in determining in what situations disqualification is appropriate. The concurring justices concluded that there was no constitutionally-based reason why a state or local legislature could not enact "appropriately defined legislation providing for ... disquahification .... in a quasi-judicial proceeding on the basis of the decisionmaker's receipt of campaign contributions "28

II

The Constitutionality of a Disqualification Standard Based on Campaign Contributions

The inajority and concurring opinions acknowledged the quality of campaign contributions as political speech, and noted that a disqualification standard triggered by such contributions would burden this first amendinent freedoin. The majority opinion suggests that the first ainendinent permits no interference with campaign contributions; the concurring opinion of Chief Justice Bird, on the other hand, concludes that legislative action in this area might well be appropriate.

The leading precedent in this area is the case of Buckley v. Valeo ${ }^{29}$ In that case, the United States Supreine Court upheld a provision of the Federal Election Cainpaign Act of 1971 that placed a limit of $\$ 1000$ per candidate on campaign contributions by individuals ${ }^{30}$ in federal elections. The Court found that the government interest in preventing corruption and the appearance of corruption in pohtics outweighed the burden on contributors' first amendment free speech and associational rights. In arriving at this decision, the Court employed a "rigorous standard of review" 31 which inquired as to whether the governmental restraint advanced a "sufficiently iniportant interest and employ[ed] a means closely drawn to avoid unnecessary abridgement of associational freedoms." 32 Justice Clark, in Woodland Hills, characterized this as a "compelling state interest" test. ${ }^{33}$

28. Id. at 953,609 P.2d at 1037, 164 Cal. Rptr. at 264 (Tobriner, J., concurring).

29. 424 U.S. 1 (1976).

30. The limit was $\$ 1000$ by a single individual or group, and $\$ 5000$ by a political committee. 18 U.S.C. $\$ 608($ b)(1), (2) (Supp. IV 1970) (repealed by Act of May 11, 1976, Pub. L. No. 94-283, 90 Stat. 496 (1976)) (campaign contributions are now limited by 2 U.S.C. $\S 441 \mathrm{la}(\mathrm{a})(\mathrm{l})(\mathrm{A}),(2)(\mathrm{A})$ (1977)).

31. 424 U.S. at 29.

32. Id. at 25 .

33. $26 \mathrm{Cal}$. 3d at 946, 609 P.2d at 1033, 164 Cal. Rptr. at 260 . The language used by the Court in Buckley is unclear as to the standard of review applied to the challenged campaign contribution limits. 424 U.S. at 25 . However, the cases cited by the Court as establishing the appropriately "rigorous standard of review," $i d$., support Justice Clark's conclusion that a compelling state interest test was utilized in Buckley. See Cousins v. Wigoda, 419 U.S. 477, 489 (1975); 
The Buckley case provides a starting point for analyzing the state interests and first amendment burdens presented by Woodland Hills. In Woodland Hills, the state interests to be served by a disqualification standard are similar to those in Buckley-the prevention of improper influence and the appearance of such in the electoral process. ${ }^{34}$ In addition, the state interests are more compelling in Woodland Hills, for the case involved the granting of a development permit, a proceeding that is quasi-judicial in character. ${ }^{35}$

Improper influence is inore likely to arise in a quasi-judicial proceeding than in a legislative proceeding simply because the degree of tolerable influence in a quasi-judicial setting is strikingly less. Impartiality on the part of the decisionmaker is an important quality in hearings that are adjudicatory in nature. This fact is illustrated by the substantial due process protections afforded parties in quasi-judicial hearings. ${ }^{36}$ So long as impartiality reinains a quahty of quasi-judicial decisionmakers, any influence on such a body is susceptible to being labeled improper. In comparison, the legislative process is designed to accommodate dialogue and influence. The well recognized influence of special interest groups on legislative bodies, ${ }^{37}$ for exainple, is not itself

NAACP v. Button, 371 U.S. 415, 439 (1963); Bates v. City of Little Rock, 361 U.S. 516,524 (1960); NAACP v. Alabama, 357 U.S. 449, 463 (1958); Sweezy v. New Hampshire, 354 U.S. 234, 265 (1957) (Frankfurter, J., concurring). See also Note, Citizens Against Rent Control v. City of Berkeley: Constitutionality of Limits on Contributions in Ballot Measure Campaigns, 69 CAL. L. Rev. 1001, 1003 \& n.13 (1981).

34. Justice Clark's declarations that adequate protection against corruption can be found in the conflict of interest laws and bribery statutes, $26 \mathrm{Cal}$. 3d at 947,609 P.2d at 1033, $164 \mathrm{Cal}$. Rptr. at 260 , may be an attempt to indicate that these alternatives reduce the intensity of state interest and therefore render further restrictions on contributions unnecessary and thus unconstitutional. The Buckley Court faced and dismissed the same argument:

[L]aws making crimmal the giving and taking of bribes deal only with the most blatant and speciflc attempts of those with money to influence governmental action. And . . Congress was surely entitled . . . to deal with the reality or appearance of corruption mherent in a system permitting unlimited financial contributions, even when the identities of the contributors and the amounts of their contributions are fully disclosed. 424 U.S. at 27-28.

35. City of Fairfield v. Superior Court, 14 Cal. 3d 768, 773 n.1, 537 P.2d 375, 377 n.1, 122 Cal. Rptr. 543, 545 n.1 (1975); $c f$. Topanga Ass'n for a Scenic Community v. City of Los Angeles, 11 Cal. 3d 506, 514, 522 P.2d 12, 17, 113 Cal. Rptr. 836, 840 (1976) (granting of variances is also quasi-judicial).

The provisions of Cahifornia's administrative mandamus statute provide the defining characteristics of a quasi-judicial action: "a proceeding in which by law a hearing is required to be given, evidence is required to be taken and discretion in the determination of facts is vested in the inferior tribunal, corporation, board or office . . ." C CAL. CIv. Proc. Code $\S 1094.5$ (West 1980).

36. See American Cyanamid Co. v. F.T.C., 363 F.2d 757, 763-64 (6th Cir. 1966).

37. See generally L.L. Berg, H. HAHN \& J.R. SchmidHAuSER, Corruption IN THE AMERICAN Political System (1976):

What has happened to the reformer's dream of a professional legislator, informed, well-advised, and exercising judgment on behalf of his constituents? Money has happened. Campaign costs mar the dreams . . . . To succeed, legislators cannot be totally 
improper.

Moreover, the appearance of fairness arguably becomes a more pressing state interest in a quasi-judicial proceeding. The government stands to be discredited inore readily in this instance than in executive and legislative proceedings. Parties to the hearing are more directly affected by an adverse decision. They will inore likely monitor the proceeding, realizing that the effects of a decision will not be diffused, as is so often the case in legislation, nor will it entail a compromise as a political tradeoff. The legitimacy of this governmental process rests $\mathrm{m}$ the appearance that it is free from leverage by one of the parties.

The constitutional values burdened in Woodland Hills are identical to those impinged in Buckley. The court held that contributions to political campaigns are "an exercise of fundamental freedoms protected by the First Amendment of the United States Constitution."38 Some burdens, however, are perınissible. The Buckley court found that a contribution's coinmunicative value derives mainly from its expression of support; thus, a limit on the amount of contributions would be only a "marginal restriction upon the contributor's ability to engage in free communication." 39 Even in those cases in which burdens have been deemed impermissible, both the United States Supreme Court and the California Supreme Court have analyzed state interests and the extent of interference with commumication before voiding the statute involved. ${ }^{40}$ In Woodland Hills, however, the majority made the initial analytical step-the characterization of cainpaign contributions as speech-the end of its constitutional analysis.

The burden imposed by use of a disqualification standard in the Woodland Hills context would depend heavily on the nature of the standard. It is likely that such a standard would create a lesser burden than the limit in Buckley. First, although the actual effeet may be nearly the same, a disqualification standard would not prohibit any

divorced from those who have the money they need . . . . In short, the old bribe of cash to the legislator has been supplemented-if not replaced totally-by the new, far more costly transfer of financial resources, cash and otherwise, to the campaign treasury. Id. at 138-39.

38. 26 Cal. 3d at 946, 609 P.2d at 1033, 164 Cal. Rptr. at 260. Justice Clark also noted that contributions are protected by article I, section 2 of the California Constitution. Id.

39. 424 U.S. at 20-21.

40. See, e.g., Bellotti v. First National Bank, 436 U.S. 765 (1977) (Massachusetts statute forbidding certam expenditures by banks and corporations for the purpose of influencing votes on referendum issues in which they had no material imterest declared unconstitutional); Hardie v. Fong Eu, 18 Cal. 3d 371, 556 P.2d 301, 134 Cal. Rptr. 201 (1976), cert. denied, 430 U.S. 939 (1977) (voiding Cahfornia statute limiting expenditures for circulating petitions to qualify statewide ballot measures); Citizens for Jobs and Energy v. Fair Political Practices Comm'n, 16 Cal. 3d 671, 547 P.2d 1386, 129 Cal. Rptr. 106 (1976) (voiding limitation on expenditures for or against statewide ballot proposition). 
contributions, ${ }^{41}$ it would only require disqualification of the recipient. More importantly, such a standard would only burden parties whose interests might come before the quasi-judicial body in question. ${ }^{42}$

Beyond that, the burden imposed will depend on the specificity of the standard. A disquahification statute must be specific lest it be susceptible to attack on the grounds of vagueness. Vagueness attacks are appropriate when a statute that does not on its face reach protected activity has the effect of burdening protected activity because its limits are not well-defined. ${ }^{43}$ In this case, a disqualification standard purports to address corrupt influence, which is not protected, but may discourage noncorrupt contributors as well. Any flexible standard would lead potential contributors to "steer far wider of the unlawful zone' . . . than if the boundaries of the forbidden areas were clearly marked."44

Both the vagueness and the burden could be reduced by formulating specific rules that would create "safe harbors" for potential contributors. $^{45}$ In view of Buckley's conclusion that the primary first amendment value of contributions coines from the expressive force of their existence rather than their amount or form, all citizens must be

41. Justice Clark noted that while disqualification did not amount to a prohibition of contributions, it would ultimately deprive the class of contributors of the constitutional right to participate in the electoral process because of the threat of silencing their representative in government. $26 \mathrm{Cal}$. 3d at 946-47, 609 P.2d at 1033, 164 Cal. Rptr. at 260.

42. For example, contributors could support with impunity candidates who might be favorable to their interests in legislative matters.

43. See generally Note, The Void-for-Vagueness Doctrine in the Supreme Court, 109 U. PA. L. REV. 67 (1960): "[T]he doctrine of unconstitutional indefiniteness has been used by the Supreme Court almost invariably for the creation of an insulating buffer zone of added protection at the peripheries of several of the Bill of Rights freedoms." Id. at 75.

44. Baggett v. Bullitt, 377 U.S. 360, 372 (1964) (quoting Speiser v. Randell, 357 U.S. 513, 526 (1958)). See generally Grayned v. City of Rockford, 408 U.S. 104 (1971). That court suminarized the defects of vague laws:

Vague laws offend several important values. First, because we assume that man is free to steer between lawful and unlawful conduct, we insist that laws give the person of ordinary intelligence a reasonable opportunity to know what is prohibited, so that he may act accordingly.... Second, if arbitrary and discriminatory enforcement is to be prevented, laws must provide explicit standards for those who apply them. . . . Third, but related, where a vague statute "abut[s] upon sensitive areas of basic First Ainendinent freedoms," it "operates to inhibit the exercise of [those] freedoms."

Id. at 108-09 (footnotes omitted). In the Woodland Hills context, the constitutional chilling effect would be increased by the contributor's inability to control the actions of the recipient of his contributions. See notes 104-05 and accompanying text infra.

The potential for vagueness is likely to be exacerbated by the possibility that a prospective contributor will be in a position to unknowingly disqualify a sympathetic officeholder because of prior or subsequent actions by either the candidate himself or other contributors. See notes 10608 and accompanying text infra. To continue the constitutional metaphor, the problem here is not only that the contributor will "steer far wider of the lawful zone"; having the culpability of his behavior depend upon the independent behavior of others might keep the contributor from ever getting behind the wheel.

45. The legislature would appear to be better suited for this task than the judiciary, although the latter might be able to set sufficient guidelines to withstand constitutional scrutiny. 
allowed to inake contributions that would not jeopardize their interests. A simple method of achieving this would be to exeinpt from scrutiny all contributions below a certain value. Such a method would allow all the first amendment expression that was available under Buckley. Since the state interest against undue influence is just as great, such legislative protection would appear to be valid. The addition of more precise limitations on contributions above the threshold amount would serve to reduce the burden while ensuring constitutionality. Other precisely defined schemes might also be valid, but are more difficult to assess since they would not be directly comparable to Buckley.

\section{III \\ Statutory and Policy Analysis}

In determining whether the association had received a fair hearmg, the court based its opimion on statutory grounds, in addition to the previously discussed constitutional considerations. The court held that the legislature had already acted to prevent corruption in politics by enacting the Political Reform Act. While the legislature addressed improper financial interests, campaign contributions were exphicitly excluded as a corruptimg imfluence. The court would not override that determination.

The concurring justices each generally agreed with this analysis. Justice Tobriner, for example, stated that "the majority correctly holds that in the absence of [a disqualification] provision the fact that a decisionmaker has received a campaign contribution does not automatically demonstrate bias or the appearance of bias. The receipt of such a contribution does not preclude the decisionmaker's participation ... ."46 However, the concurring justices feared that the majority meant to rule out all action in this field, includimg legislative reforin. ${ }^{47}$ Each argued that the adequacy of current protections was peculiarly a legislative determmation rather than one for the courts and that the legislature could enact further safeguards if it felt the need to do so.

In fact, all of the justices took too narrow a view of the judicial role. The courts have a responsibility to determine the adequacy of legislative protections in light of applicable policy considerations as well as statutes. Instead of basing the refusal to disquahify the council members only on the absence of a disqualifying statute, the court sliould have based its decision on broader policy grounds. By neglect-

46. 26 Cal. 3d at 953, 609 P.2d at 1037, 164 Cal. Rptr. at 264.

47. See id. at 951, 609 P.2d at 1036, 164 Cal. Rptr. at 263 (Bird, C.J., concurring) ("II]t is not the place of this court to declare, as does the majority, that "[a]dequate protection against corruption and bias is afforded through the Pohtical Reform Act and crimmal sanction.' Whether or not this is true is a matter for the legislature to determine." (citation omitted)). 
ing to explicitly consider the policies implicated, the court inisled the California judiciary in two ways. It implied that courts can decide the fair trial question without a broad-based inquiry. Moreover, it treated restraints on quasi-judicial decisionmaking as burdens on representative government, without weighing the interest of impartiality in such proceedings.

\section{A. Courts Should Make a Comprehensive Determination of Fairness}

In California, the granting of use permits like the one involved in Woodland Hills is a quasi-judicial act ${ }^{48}$ and is thus subject to judicial review through a writ of administrative inandanus, as provided by section 1094.5 of the California Code of Civil Procedure. ${ }^{49}$ Subsection (b) of that section defines the scope of judicial review:

The inquiry in such a case shall extend to the questions whether the respondent has proceeded without, or in excess of jurisdiction; whether there was a fair trial; and whether there was any prejudicial abuse of discretion. Abuse of discretion is cstablished if the respondent has not proceeded in the manner required by law, the order or decision is not supported by the findings, or the findings are not supported by the evidence. $^{50}$

The association challenged the city council's action on the grounds of the "fair trial" provision of section 1094.5. It claimed that the receipt of contributions from the developer by the city council neinbers created an appearance of improper influence and denied the association a fair hearing on the developinent approval.

Although few California cases have relied on the fair trial provision, it can be very important in ensuring the fairness of quasi-judicial decisionmaking. Given a fair hearing, reviewing courts einploy the deferential "substantial evidence" standard of review. ${ }^{51}$ Decisionmaking bodies will in inost cases be able to inuster sufficient evidence to support whatever conclusion they desire to reach. ${ }^{52}$ However, if a re-

48. See note 35 supra.

49. City of Fairfield v. Superior Court, 14 Cal. 3d 768, 773 n.1, 537 P.2d 375, 377 n.1, 122 Cal. Rptr. 543, 545 n.1 (1975).

50. Cal. Civ. Proc. Code $\S 1094.5$ (b) (West 1980).

51. Cal. Civ. Proc. Code $\$ 1094.5$ (c) (West 1980). In cases involving "fundainental vested rights," the court must apply a "weight of the evidence" standard, Valenzuela v. Board of Civ. Serv. Comm'rs, 40 Cal. App. 3d 557, 561, 115 Cal. Rptr. 103, 105 (2d Dist. 1974), but no such right was involved in the Woodland Hills controversy.

52. This is especially true in quasi-judicial cases involving questions of land use because often the issues in dispute are not questions of fact, but differences as to policy options. See Fairfield v. Superior Court, 14 Cal. 3d 768, 779-80, 537 P.2d 375, 381-82, 122 Cal. Rptr. 543, 55051 (1975). Accordimgly, under a standard that requires only "inore than a inere scintilla" of evidence or "evidence of ponderable legal significance," Spurrell v. Spurrell, 205 Cal. App. 2d 786, 790, 23 Cal. Rptr. 414, 417 (2d Dist. 1962), a body seeking to have an action upheld need do little more than demonstrate arguable conformity with a comprehensive plan cast in general terms. See 
viewing court suspects that a decision, though reasonable on its face, is the product of the panel's bias, it is empowered to make an independent determination of the bias question based on the hearmg record. ${ }^{53}$ On that question, it owes no deference to the original decisionmaker.

In Western Airlines v. Schutzbank,${ }^{54}$ a fair hearmg claim was based on the alleged bias of a hearing officer. The case involved several applications by the airline to the Coinmissioner of Corporations for permission to eliminate certam cumulative voting rights with respect to its stock. $^{55}$ The trial court found bias ${ }^{56}$ by relying on statements in letters and testimony by an Assistant Commissioner who participated in the determination of the case that "he believes in cumulative voting, that it is a substantial right, and that he '. . would be unable to find that the substitution of securities depriving the shareholders of the right would be fair." "57

On appeal, the Western Air Lines court of appeal looked to the hearing record for support of the trial court's independent finding of bias. It concluded that the trial court had erred. ${ }^{58}$ In the absence of any explicit statutory directive, the court looked to the law in other jurisdictions ${ }^{59}$ and to the law and policy of the state of California as expressed by judicial precedent. ${ }^{60}$

In the Woodland Hills case, likewise, in reviewing the trial court's treatment of the association's claims of unfairness, the supreme court should have taken a broader view rather than simply relymg on a single statutory limt. It should have conducted an examination of policy tradeoffs between conflicts of interest and unencumbered political speech. In the state of Washington, courts, when reviewing quasi-judicial land use decisions very similar to that involved in Woodland Hills, have taken this comprehensive approach. They have formulated a judicial appearance of fairness doctrine in the absence of a statutory directive. ${ }^{61}$ Beginning with Smith v. Skagit County, ${ }^{62}$ Washington courts

also L. Jaffe, Judiclal Control of Administrative ACTION 602 (1965) ("It matters not that the whole record will support a contrary inference or that in the opinion of the court the contrary inference is inore probable or even much tnore probable. The court may not weight the worth of competing inferences.").

53. Fairfield v. Superior Court, 14 Cal. 3d 768, 776, 537 P.2d 375, 380, 122 Cal. Rptr. 534, 547 (1975).

54. 258 Cal. App. 2d 218, 66 Cal. Rptr. 293 (2d Dist. 1968).

55. Id. at 220,66 Cal. Rptr. at 295.

56. Id. at 226, 66 Cal. Rptr. at 299.

57. Id. at 230,66 Cal. Rptr. at 301 .

58. Id. at 252, 66 Cal. Rptr. at 316.

59. Id. at 228, 66 Cal. Rptr. at 300 (citing NLRB v. Phelps, 136 F.2d 562 (5th Cir. 1943)).

60. Id. at 231-32, 66 Cal. Rptr. at 302-03 (discussing Weil v. Weil, 37 Cal. 2d 770, 236 P.2d 159 (1951)).

61. In New York, where statutes do define conflict of interest relationships in both general municipal transactions, GEN. MUN. LAW $\$ \S 800-808$ (McKinney 1974 \& Supp. 1980), and specifi- 
have set aside administrative decisions on the basis of procedural irregularities, financial conflicts, and other indicia of improper influence, relying not on state statutes but on policy grounds. ${ }^{63}$ While the doctrine has suffered froin hapliazard development, ${ }^{64}$ the courts' willingness to carefully scrutinize quasi-judicial decisionmaking to ensure fairness is laudable.

\section{B. Quasi-Judicial Decisionmaking as a Political Process}

In examining policy considerations to deterunine whether the decisionmakers in Woodland Hills should have been disqualified for receiving campaign contributions from one of the parties to the hearing, the court sliould have first considered the nature of the proceedings. The granting of developinent perunits in California is considered quasi-judicial $^{65}$ because it involves the essentially adjudicatory act of applying generalized rules to specific cases. However, such decisions are not strictly judicial. They involve important policy questions which are

cally in zonimg actions, GEN. MUN. LAw $\$ 809$ (McKinney 1974). Courts have also taken a more coinprehensive approach. One trial court invalidated a zoning board vote because of the participation of the board chairman who was also a vice president of the advertising firm used by the applicant. Although the relationship in question did not fall under any statutory category of apparent or actual inproper influence, the court held:

These few obvious categories can hardly be considered an attempt at establishing an all-imclusive list of possible conflicts . . . .

Clearly, the statutory list was meant to set forth only those situations in which there is a conclusive presuinption of a conflicting interest. It is recognized that because of the myriad possibilities of disqualifying conflicting interests in quasi-judicial matters, disqualiflcation should be a factual issue governed by the circuinstances of each case and that a definitive rule cannot be formulated.

Tuxedo Conservation and Taxpayers Ass'n. v. Town Bd. of Tuxedo, 96 Misc. 2d 1, 9-10, 408 N.Y.S.2d 668, 673 (1978), affd., 69 A.D.2d 320, 418 N.Y.S.2d 688 (1979).

62. 75 Wash. 2d 715,453 P.2d 832 (1969).

63. Washington lias no statutory sclieme analogous to California's Political Reform Act; this absence, coupled with the judiciary's willingness to analyze fact patterns for appearances of unfairness, has produced a "common law" of improper influences.

See Save a Valuable Environment (SAVE) v. City of Bothell, 89 Wash. 2d 862, 576 P.2d 401 (1978) (one planning commissioner on payroll of the local chanber of commerce, another on its executive board, the chamber of commerce having a stake in rezoning application); Swift v. Island County, 87 Wash. 2d 348, 552 P.2d 175 (1976) (commissioner who voted on prehininary approval and then left commission had interest, thereby invalidating final approval in whicl he did not participate); Narrowsview Preservation Ass'n. v. City of Tacoma, 84 Wash. 2d 416, 516 P.2d 897 (1974) (nember of board enployed by bank which lad collateral interest in proposed tract); Fleming v. City of Tacoina, 81 Wash. 2d 292, 502 P.2d 327 (1972) (city councilman ennployed by proponents of proposal); Anderson v. Island County, 81 Wash. 2d 312, 501 P.2d 594 (1972) (chairinan of body formerly owned the land involved in the application); Buell v. City of Bremerton, 80 Wash. 2d 518, 495 P.2d 1358 (1972) (member lad interest in adjoming property); Clirobuck v. Snohomish County, 78 Wash. 2d 858, 480 P.2d 489 (1971) (invalidation inandated by cumnulative inpact of unembers' social acquaintances, prior political activities and trip to applicant's hone office with food and entertainment expenses borne by applicant).

64. See Alkire, Washington's Super-Zoning Commission, 14 GonZAGA L. Rev. 559, 562-84 (1979).

65. See note 35 supra. 
legislative in nature. The decisions generally turn not on disputed facts but on whether the developinent will serve the public interest. ${ }^{66}$ Given these characteristics, a local city council, which is politically accountable to the public, is an appropriate decisionmaker.

\section{Constraints on the Decisionmaker in Quasi-Judicial and Judicial Contexts}

While a party is entitled under section 1094.5 to a fair hearing before a quasi-judicial body, just as due process requires a fair trial in judicial proceedings, ${ }^{67}$ the standard of fairness is different in the two contexts. The differences in state statutes concerning the disqualification of decisionmakers serve to illustrate this point. Most public officials in California are subject to the state's Political Reform Act. ${ }^{68}$ Judges, however, are subject to separate statutory and nonstatutory proscriptions that parallel and frequently exceed those placed upon other decisionmakers. ${ }^{69}$ The California Code of Judicial Conduct ${ }^{70}$ and section 170 of the Code of Civil Procedure specify personal, family, financial, and professional relationships that require judicial recusal. ${ }^{71}$ The legislature has also "guaranteed to litigants the extraordinary riglit to disqualify a judge"72 by allowing parties im civil or criminal actions one peremptory cliallenge to be automatically granted upon the timely presentation of an oath or affidavit alleging bias. ${ }^{73}$ The absence of these safeguards in the quasi-judicial context refleets the lesser empliasis on coinplete neutrality and dispassionate factfinding. The added dimensions of quasi-judicial decisionmaking require

66. See City of Fairfield v. Superior Court, 14 Cal. 3d 768, 780, 537 P.2d 375, 382, 122 Cal. Rptr. 543, 550 (1975).

67. Le Strange v. City of Berkeley, 210 Cal. App. 2d 313, 325, 26 Cal. Rptr. 550, 558 (1st Dist. 1962).

68. CAL. Gov'T CODE $\S \S 81000-81016$ (West 1976 \& Supp. 1980). "No public official at any level of state or local government shall make, participate in making or in any way attempt to use his official position to infiuence a government decision in whieh he knows or has reason to know he has a financial interest." Id. $\$ 87000$.

69. CAL. GOV'T CODE $\S 82048$ defines public officials as "every membcr, officer, employee or consultant of a state or local government agency;" $\S 82048$ excludes courts and other agencies of the judiciary from the Act's coverage.

70. CAL. R. of CT., APp., Div. II (Deering 1980 \& Supp. 1981).

71. CAL. CIV. Proc. CODE $\S 170(1)-(4)$ (West Supp. 1980). An example of the more severe prohibitions on jndges is the treatment of any capital stock, note, bond or security as a disqualifying financial interest. Id. $\S 170$ (2). For all other public officials, the investment must be worth $\$ 1,000$ or more to constitute a legal conflict of interest. CAL. Gov'T CODE $\$ 87103$ (West 1976).

72. McCartney v. Commission on Judicial Qualifications, 12 Cal. 3d 512, 531, 526 P.2d 268, 281, 116 Cal. Rptr. 260, 273 (1974).

73. CAL. Civ. Proc. Code $\S 170.6$ (West 1976 \& Supp. 1980). A judge can also be challenged for prejudice or bias under $C_{A L}$. Civ. Proc. CODE $\$ 170(5)$ (West Supp. 1980). Such a challenge, like the others under the same section, calls for a neutral determination that grounds for disqualification exist, rather than simply the oath of a party. 
that the desire to satisfy the contestants and the general public that proceedings are perfectly impartial inust be tempered by the desire for specialized expertise in the case of administrative bodies ${ }^{74}$ or popular input in the case of representative bodies. ${ }^{75}$ The Woodland Hills case illustrates the latter type of case, in which the desirability of political responsiveness necessarily conflicts with any notion of impartiality on the part of individual decisionmakers.

In quasi-judicial contexts like that in Woodland Hills, where the decisionmakers are also legislators, the electoral procedures of the decisionmakers are in sharp contrast to those of judges, illustrating their more political role. In California, city council unembers hold office for four years, ${ }^{76}$ while judges serve substantially longer ternis. ${ }^{77}$ In addition, appellate judges are only subject to voter confirmation, and not contested elections. ${ }^{78}$ Elections for trial judges may be contested, but often are not. ${ }^{79}$ In contrast, city council inembers inust often participate in hotly contested elections. Most importantly, while running for a legislative office like the city council inevitably involves campaigning, making speeches, and statimg one's views on political issues, judges must conduct their campaigns differently. The ABA's Code of Judicial Conduct, adopted in California in 1975 and applicable to candidates for judicial office, requires judges to "refrain from political activity inappropriate to . . judicial office." 80 This requirement has been interpreted as placing severe constraints on the kinds of political activity a campaigning judge may engage in. ${ }^{81}$ Judges are, as inucli as possible, insulated from political pressures; those legislators who occasionally serve as quasi-judicial decisionmakers, on the other hand, are fully and continuously subjected to political influences.

\section{Impact of Political Processes on Quasi-Judicial Decisionmaking}

The California courts have explicitly endorsed quasi-judicial dccisionmaking by elected officials, recognizing the integration of the political process with the adjudicatory posture of the proceedings. In City of

74. See $2 \mathrm{~K}$. Davis, Administrative LaW $\S 12.03$ (1958).

75. See notes $82-93$ and accompanying text infra.

76. CAL. Gov'T CODE $\S 36503$ (West 1981).

77. CAL. Const. art. 6, § 16(a), (c) (West 1981) (supreme court and court of appeal justices serve for 12 years; superior court judges serve for six years).

78. Cheit \& Golzé, Are Sitting Judges Sitting Ducks? The Case for Abolishing Judicial Elections, 55 CAL. ST. B.J. 414, 415 (1980).

79. Dubois, Are Sitting Judges Sitting Pretty? A Rejonder to Cheit and Golzé, 56 CAL. ST. B.J. I24 (1981) (in the June 1980 elections, ninety percent of all incumbent trial court judges were not challenged).

80. Cheit \& Golzé, supra note 78 , at 415.

81. Id. 
Fairfield v. Superior Court, ${ }^{82}$ the California Supreme Court stated that public statements by candidates for city council that reflected their opinions on certain land use questions did not rcquire the members' subsequent disqualification when the council acted on those issues in a quasi-judicial capacity.

In Fairfield, the city council denied a developer's application for a use permit to construct a slopping center. The developer petitioned the superior court for administrative mandamus, claiming that the council had denied it a fair hearing. The developer contended that prior to the learing, two members of the city council had publicly stated their opposition to the shopping center. ${ }^{83}$ To prove the claim, the developer sought to depose the two council members. When they refused to answer certain questions, the trial court ordered them to do so. The supreme court lield that the trial court's order was invalid because the developer had not shown sufficient justification for the questions. ${ }^{84}$ However, "for the assistance of the parties in further proceedings in this litigation," ${ }^{\prime 85}$ the court discussed the substance of the developer's claim.

The court stated that even if the council members did state their opposition to the shopping center before the hearing, this would not require them to disqualify themselves from voting on the apphication. ${ }^{86}$ That decision, the court noted, did not turn on an adjudication of facts, rather it turned on policy considerations. The decision would significantly affect a broad range of civic issues, mcluding the economic growtl of the city, its revenue and expenditures, and traffic and pollution problems. ${ }^{87}$ The court stated "[a] councilman has not only a right but an obligation to discuss issues of vital concern with his constituents and to state his views on matters of public importance." 88

The court noted that many of the alleged statements indicating the "bias" of the council members took place during their election campaigns, and specified that such statements do not constitute cause for subsequent disqualification:

[I]t would be contrary to the basic principles of a free society to dis-

82. 14 Cal. 3d 768, 537 P.2d 375, 122 Cal. Rptr. 543 (1975).

83. Id. at $772-73,537$ P.2d at 377,122 Cal. Rptr. at 545.

84. The court held that Code of Civil Procedure $\S 1094.5(\mathrm{~d})$ governs discovery in an action for administrative mandamus and that the developer had not met its burden of showing that the evidence it sought " "could not have been produced or . . . was improperly excluded at the hearing . . . " Id. at 775, 537 P.2d at 378, 122 Cal. Rptr. at 546 (quoting CAL. Clv. Proc. Code $\S 1094.5(\mathrm{~d})$ (West 1980)).

85. 14 Cal. 3d at 777, 537 P.2d at 380, 122 Cal. Rptr. at 548.

86. Id. at 782,537 P.2d at 383,122 Cal. Rptr. at 551 .

87. Id. at 780,537 P.2d at 382, 122 Cal. Rptr. at 550.

88. Id. See also Todd v. City of Visalia, 254 Cal. App. 679, 62 Cal. Rptr. 485 (5th Dist. 1967). 
qualify from service in the popular assembly those who had made preelection commitments of policy on issues imvolved in the performance of their sworn . . . duties. Such is not the bias or prejudice upon which the law looks askance ... . The contrary rule of action would frustrate freedom of expression for the enlightenment of the electorate that is of the very essence of our democratic society. ${ }^{89}$

The Fairfield court reiterated this last point in disapproving the case of Saks \& Co. v. City of Beverly Hills ${ }^{90}$ In that case, three people were elected to the city council by campaigning on a platform that called for the revocation of certain parking variances. After their election, the plamtiff, who held one such variance, sought to have the three disqualified from voting on its revocation. The court of appeal upheld the trial court's order disquahifying the council members due to their demonstration of bias and prejudice in advance of the hearings. The Fairfield court disapproved this holding, stating that it "effectively thwarted representative government by depriving the voters of the power to elect councilmen whose views on this important issue of civic pohicy corresponded to those of the electorate."91 Under the pohicy analysis of the Faiffeld court, the fact that a quasi-judicial decisionmaker has known opmions on questions of policy is not a sign of bias. Moreover, such candidates should make their views known so that the electorate can effectively exert its mfluence on the government.

Fairfield approved the integration of pohtics with quasi-judicial decisionmakmg. Where Fairfield mvolved the pubhizizing of opimions in order to gain popular support, Woodland Hills involved a manifestation of popular support in the form of campaign contributions. Woodland Hills thus dealt with the interaction between the candidate and members of the public that Fainfield determined does not taint the quasi-judicial process. The association never alleged that these contributions were bribes. Rather, they were legal contributions which serve the symbolic purpose of demonstrating the support of the contributor for the candidate, and the practical purpose of providing the candidate with funds. The state of Cahfornia has in effect endorsed contributions by relymg solely on private funding for political campaigns rather than

89. 14 Cal. 3d at 781, 537 P.2d at 383, 122 Cal. Rptr. at 551 (quoting Wollen v. Fort Lee, 27 N.J. 408, 414, 142 A.2d 881, 888 (1958). The court then listed the leading cases in accord with Wollen from other jurisdictions: Binford v. Western Elec. Co., 219 Ga. 404, 133 S.E.2d 361 (1963); Moskow v. Boston Redev. Auth., 349 Mass. 553, 210 N.E.2d 699 (1965), cert. denied, 382 U.S. 983 (1966); City of Farmer's Branch v. Hawnco, lnc., 435 S.W.2d 288 (Tex. Civ. App. 1968).

90. 107 Cal. App. 2d 260, 237 P.2d 32 (2d Dist. 1951).

91. 14 Cal. $3 \mathrm{~d}$ at 782, 537 P.2d at 383, 122 Cal. Rptr. at 551. While the Woodland Hills majority does not cite Faiffield, the tenor of the opinion is reminiscent of Fairfield. The Woodland Hills court stated "[r]epresentative governinent would be thwarted by depriving certain classes of voters . . of the constitutional right to participate in the electoral process." $26 \mathrm{Cal} .3 \mathrm{~d}$ at 947,609 P.2d at 1033, 164 Cal. Rptr. at 260. 
public financing. ${ }^{92}$

Disqualifying quasi-judicial decisionınakers from deciding matters before them on the basis of their receipt of campaign contributions would inhibit the electorate from exerting its influence on local policy through campaign contributions. In Woodland Hills, the court recognized the public policy in favor of campaign contributions, ${ }^{93}$ but rested its opinion solely on constitutional considerations and the Political Reform Act. Instead, it should have used the policy analysis of the Fairfield court, examining independently the issue of fairness, and weighing the extent of the burden on political processes. Such an analysis would show that a fairness test based on the receipt of campaign contributions would be an undesirable solution, whether formulated by the courts or by the legislature.

\section{A Fairness Standard Based on Campaign Contributions Would Unduly Burden Political Processes}

While reviewing any administrative action pursuant to section 1094.5, a court must consider fairness. Had the Woodland Hills court independently considered whether a fair hearing was provided to the parties, it still would not have called for the disqualification of the contribution recipients. The entanglement of the political process in quasijudicial proceedings will not render such hearings unfair; indeed, political responsiveness and accountability are accepted features of the process. $^{94}$ Any judicial or legislative fairness standard scrutinizing legal contributions given to a decisionmaker would unduly burden this accepted form of political communication. ${ }^{95}$

92. An example of a contrasting system that relies upon a combination of private contributions, public matching of certain contributions (under \$100), and public financing of general election races is the series of federal statutes governing the financing of presidential election campaigns. See Buckley v. Valeo, 424 U.S. 1, 85 n.114 (1976).

In California, the Political Reform Act deals with contributions by requiring their disclosure by the candidate. Thus, the Act rehes on public scrutiny and public opinion to police contributions. See CAL. Gov'T CODE $\$ 81002$ (West Supp. 1980) which reads in part: "The people enact this title to accomplish the following purposes: (a) Receipts and expenditures in election campaigns should be fully and trnthfully disclosed in order that the voters may be fully informed and improper practices may be inhibited . . . ." The statute moreover speaks to official impartiality, in light of contributions: "Public officials, whether elected or appointed, should perform their duties in an impartial manner, free from bias caused by their own financial interests or the financial interests of persons who supported them . . . ." Id. $\$ 81001$ (b) (West 1976).

93. $26 \mathrm{Cal} .3 \mathrm{~d}$ at 947,609 P.2d at 1033, $164 \mathrm{Cal}$. Rptr. at 260.

94. Even while formulating a judicial appearance of fairness doctrine, the Washington Supreme Court remained acutely aware of the importance of the electoral process in the sphere of quasi-judicial decisionmaking, recognizing that the members of a body making a decision like that in Woodland Hills should not attempt to ignore their own opinions on matters of civic importance. "Indeed, the election of legislators is often based on their announced views and attitudes on public questions." Smith v. Skagit County, 75 Wash. 2d 715, 740, 453 P.2d 832, 847 (1969).

95. The Washington courts have never held that campaign contributions can create an ap- 
This is not to say that campaign contributions never actually exert a corruptimg influence on politicians. Not only is it generally accepted that contributions may be a source of corruption, but in the Woodland Hills case itself there was some public suspicion of actual corruption. ${ }^{96}$ In considering the legitimacy of particular campaign contributions, those mstances where a candidate's views are rooted in the pockets of contributors are different from the model situation in which financial support comes as a result of a candidate's prior views. The former involve the type of improper influence that statutes like the Federal Election Campaign Act of $1971^{97}$ were enacted to guard agamst.

The difference between the model and the improper campaign contribution lies in the intent of the actors. Since the actions of the parties may be outwardly indistinguishable, it is likely to be difficult, if not impossible, to separate these two situations. Under a judicial doctrine by which courts would examine all the circumstances to determine whether any improper imfluence had occurred, one problem would be inaccuracy. When called upon to determine such a difficult question of intent, courts are likely to be ineffective despite their general expertise in factfinding. ${ }^{98}$

pearance of bias. In Save a Valuable Environment (SAVE) v. City of Bothell, 89 Wash. 2d 862, 576 P.2d 401 (1978), the two commission members associated with the local chamber of commerce-one as the paid executive director, another as a member of the organization's executive board-asserted a first amendment defense: the right of association. The court reasoned that their contention was not valid. "The rule does not prohibit membership in community organizations; it prohibits participation in at least quasi-judicial proceedings when such membership demonstrates the existence of an interest which might substantially influence the individual's judgment." Id. at 874, 576 P.2d at 407-08.

While this rule applies to associational conflicts of interest, it is not so readily extended to conflicts of interests arising from the receipt of contributions. If campaign contributions were the subject of the faimess inquiry, elected officials who had already accepted contributions would find themselves in a constitutionally untenable position unlike that of the $S A V E$ defendants. The latter could, without unduly disturbing their own constitutional interests or those of their organization, resign from the organization or reduce their involvement in it so that it would no longer represent a "substantially influencing interest" in a proceeding they will help decide. For the elected representative, the inability to disassociate himself or herself from an earlier accepted contribution could lead to refusals by candidates of contributions and thereby amount to a restraint upon the contributors' exercise of first amendment rights.

96. The practice of contribution solicitation by members of the city council's planning committee received prominent attention in the media and was cited to the supreme court. Brief for Residents Association, supra note 11 , at 34-35 \& n.8. The brief cited two published reports: Councilman Asks Funds of Applicants Before Him, Los Angeles Times, Dec. 6, 1978, § I, at 1; Fellow Constituents and, ahem, Moneyed Developers . . . : The oddly swelling coffers of Councilman Art Snyder, Los ANGEles MaGazine, Apr. 1978, at 98.

97. 2 U.S.C. $\$ \S 431-455 ; 18$ U.S.C. $\$ \$ 591-607$ (1976). The 1971 Act was amended by the Federal Election Campaign Act Amendments of 1974, Pub. L. No. 93-443, 88 Stat. 1263 (1975). Buckley v. Valeo, 424 U.S. 1 (1976), concerned the Act and the 1974 amendments.

98. See Celler, Pressure Groups in Congress, 319 AnNals 4-5 (Sept. 1958):

$[T]$ he candidate himself has difficulty in determining to what extent he owes a campaign contribution to recognition of his qualities of statesmanship and to what extent it reflects approval of his particular past or anticipated action on a matter close to the contributor's 
The primary disadvantage of a disqualification standard, however, is that it would strongly discourage potential contributors. ${ }^{99}$ This effect stems froin the flexibility inherent in the judicial approach. If the courts are willing to exainine any evidence that might indicate corrupt intent, it will be difficult for any contributor to be certain that he or she is not acting suspiciously. ${ }^{100}$ For example, when patterns of contributions to several decisionmakers are involved, a judicially imposed standard could very well condemn those actions which, standing alone, would warrant little criticism. ${ }^{101}$ In her Woodland Hills concurrence, Chief Justice Bird noted the array of factors that could be relevant in judging the appearance of bias, including "the amount of the contribution, its timing, its inethod, as well as the significance of the issue being considered." 102 Reliance upon those factors, however, could easily cause a contributor who has no control over future behavior of candidates, subsequent actions of other contributors or the injection of issues into public debate to refrain froin making a demonstration of support.

The ever-present threat of a judicial finding of bias would inhibit proper contributions by those fearful of disqualifying an official whose favorable vote they inight have legitimate cause to expect. A rational contributor faced with a candidate whom he beheved to be in agreement with him on questions of land use policy would be less likely to make a contribution if the candidate might be disqualified when the contributor appears before the council. Environmentalists as well as developers would be in a paradoxical situation: the candidates they consider most worthy of support would be the very ones to whom they would most strongly avoid contributimg financial assistance.

Similarly, if a disqualification standard is also applied to the representatives and agents of potential parties to quasi-judicial actions, con-

heart. It begs the question to say that such contributions are proper when the purpose for which they are given is the election of the candidate and not the purpose of influencing his vote.

99. Though the effect may be the same, the issue here is not the "chilling" of expression in the constitutional sense, see notes 29-45 and accompanying text infra, but simply the defeat of the state policy favoring community input into policy grounded quasi-judicial decisions like that in Woodland Hills.

100. An intent test occurs primarily in the criminal context. In criminal cases, however, the "reasonable doubt" standard of proof routinely resolves the uncertainties in favor of the defendant. See In re Winship, 397 U.S. 358, 363 (1970) (reasonable doubt standard reduces the "risk of convictions resting on factual error").

101. The court of appeal's decision in the Woodland Hills case may have involved just such an undeserved "broad stroke" disqualification. One councilman, Robert Wilkinson, received two $\$ 120$ contributions-one from Lathain \& Watkins and one from an individual associated with Spindler Engineering -in late October, 1975, alnost a year-and-a-half before the city council considered the subdivision for the second time. Both the timing and the low total of the contributions call into question the improper intent. Nevertheless, Councilman Wilkinson was adjudged disqualified by the court of appeal. See note 17 supra.

102. 26 Cal. 3d at 950-51, 609 P.2d at 1036, 164 Cal. Rptr. at 262. 
tributions would be made at considerable risk. Large law firms and lawyers associated with them, for instance, would have to assess the possibility that current or future clients might appear before the elected body before contributing to incumbents or challengers. ${ }^{103}$ The inhibition of these contributions cannot be justified as curbing donors from acting only in self-interest rather than on the basis of any greater principle: a substantial and long-standing school of thought contends that self-interest is precisely the principle that should motivate behavior in the political arena. ${ }^{104}$

This discouraging effect is magnified by the fact that the potential contributor cannot control the actions of the candidate. This presents a second dilemma to the contributor. If a developer were to contribute to the city council candidate, he would risk the possibility that that candidate might shortly afterward make a speech, or if an incumbent, begin or continue in a pattern of voting that would later make the contribution appear suspicious.

This inhibition of political contributions would have two adverse effects on the electoral process. First, it would dampen the input of community views, the sanie effect deplored by the Fairfield court. In addition, a significant decrease in the flow of private contributions would enhance the political advantage available to personally wealthy candidates, an advantage considered inconsistent with democratic ideals. $^{105}$

103. Additionally, there is the question of how to treat contributions from organizations such as large law firms, which often have connections-financially and personally-to opposing candidates. On the one hand, such behavior accommodates a valid goal in equalizing political resources and should be encouraged. On the other hand, "playing both sides" indicates an interest in maintaining goodwill with, and access to, whoever happens to win the election. Nevertheless, spreading of contributions by law firms inight not present a strong case for disqualification: if the winner of an election receives a contribution from any individual or group that also contributed to the opposition, the amount of goodwill "purchased" should-given full disclosure of all donations-be reduced accordingly. Some kind of offset night thus be in order when calculating contribution receipts for purposes of determining disqualification. Yet, however conceptually proper such an offset mechanism is in theory, judicial application would be cumbersome and problematic.

104. One of the earliest articulations of this theory, at least in the American context, appears in James Madison's The Federalist:

A landed interest, a manufacturing interest, a mercantile interest, a moneyed interest, with many lesser interests, grow up of necessity in civilized nations, and divide them into different classes, actuated by different sentiments and views. The regulation of these various and interfering interests forms the principal task of modern legislation and involves the spirit of party and faction in the necessary and ordinary operations of the government.

The Federalist No. 10 (J. Madison) 131 (B.F. Wright ed. 1961).

105. In a 1907 speech President Theodore Roosevelt advocated not only full campaign financing disclosure, and a ban on corporate contributions, but also the adoption of public financing of campaigns. Roosevelt offered two rationales for what he acknowledged was a radical departure from inore limited reforms:

There is . . . always danger in laws . . . which from their very nature are difficult of 
A judicial approach would thus significantly interfere with campaign contributions. The concurring justices in Woodland Hills suggested that the legislature is better equipped to deal with the problem. However, a legislative standard for disqualification would be no better. Chief Justice Bird stressed that while the judiciary is not equipped to "hammer out the proper standards for disqualification based solely on the receipt of lawful campaign contributions," the legislature is. ${ }^{106}$ As Chief Justice Bird suggested, the legislature could set down numerous categories of parties, amounts of contributions, and contribution patterns that would automatically trigger disqualification. ${ }^{107}$

A legislative disquatification standard would nevertheless be an undesirable response to the possibility of improper influence on quasijudicial proceedings due to campaign contributions. Such a statute might defeat the legitimate expectations of "innocent" contributors, and could routimely be evaded by corrupt contributors. As to the former drawback, the well-intentioned contributor will be penalized for his participation in the political process, at a time when his interests are most at stake, because disqualification of the council member sitting as a quasi-judicial officer would be automatic.

A further problem lies in drafting a statute that is neither vague ${ }^{108}$ nor so specific as to be susceptible to evasion. A statute may be geared toward timing, for example, by mandating disqualification when a con-

enforcement; the danger being lest they be obeyed only by the honest, and disobeyed by the unscrupulous, so as to act only as a penalty upon honest men. Moreover, no stuch law would hamper an unscrupulous man of unlimited means from buying his own way into office.

H.R. Doc. No. 1, 60th Cong., 1st Sess., pt. I at XLVII (1910), quoted in Buckley v. Valeo, 519 F.2d 821, 836 (D.C. Cir. 1975), affd in part, rev'd in part, 424 U.S. 1 (1976) (emphasis added).

Large political contributions are widely condemned; however, they are merely the most conspicuous examples of a larger problem - the effeets of concentrations of wealth on the electoral process. In United States v. U.A.W., 352 U.S. 567 (1956), Justice Frankfurter, writing for the majority, surveyed early twentieth century social and political history in support of the contention that there was a "lively . . popular feeling that aggregated capital unduly influenced politics . . . ." Id. at 570. "The power of wealth threatened to undermine the political integrity of the Republic." 2 S. Morison \& H. Commager, The Growth OF the AmErican RepUblic 355 (4lh ed. 1950), quoted in United States v. U.A.W., 352 U.S. at 570. See generally id. at 570-77.

For a more recent expression of this concern about the consequences of unequal financial resources in politics, see Citizens Against Rent Control v. City of Berkeley, 27 Cal. 3d 819, 826-27, 614 P.2d 742, 746, 167 Cal. Rptr. 84, 88 (1980), prob. juris. noted, 49 U.S.L.W. 3616 (U.S. Feb. 23, 1981) (No. 80-737) (upholding contribution limitations in local initiatives because "the domination of these processes by large contributors leaves other citizens with a stilled voice in the very domain of our electoral system set aside for accomplishing the popular will."). But see First Nat'l Bank of Boston v. Bellotti, 435 U.S. 765 (1978). See also Note, supra note 33.

106. $26 \mathrm{Cal}$. 3d at 950,609 P.2d at 1036, 164 Cal. Rptr. at 262. Chief Justice Bird also suggested that the legislature is more capable of determining the adequacy of present protections. Id. at 951, 609 P.2d at 1036, 164 Cal. Rptr. at 262. For the view that courts should make an independent fairness determination, see notes 48-64 and accompanying text supra.

107. See note 102 and accompanying text supra.

108. See notes $43-45$ and accompanying text supra. 
tribution has been made withm a certain time period before the hearing. Contributors, however, will always be able to frustrate temporal controls. Ironically, those contributors who are legitimately trying to elect candidates with congenial views will more likely trigger disqualification; those who are simply colluding with officials to extract favors will structure their payoff scheines to insure that they will withstand scrutiny. In addition, contributions that follow a favorable action may appear more suspicious to the public, and may in fact be more worrisome. Yet this type of arrangement would be the most difficult for a disqualification statute to address. To do so would require overturning decisions already made, perhaps months or years before, ${ }^{109}$ rather than affecting the decisionmaking process at the time of the hearing. ${ }^{110}$

Regardless of the amount and timing standards set, individuals or groups of interested parties could slelter their contributions by contributing through political action committees, thus masking the actual source of the funds. Alternatively, contributors could use organizations to mingle their contributions with those of disinterested parties. Thus, even if the identities of all contributors were known, the impact and manner of any single contribution might be obscured, perhaps eliminatimg it from one of the statutory categories. ${ }^{11}$ Even more complex schemes can be imagimed. A group of developers could agree to each "sponsor" a simgle different city council member, so that the disqualification statute would operate to leave a distinctly prodevelopment majority on the council when any of the developers liad an application pending. Justice Clark even suggested that imterested parties might deliberately make nominal contributions to candidates witl unfavorable views in order to have them disqualified from voting adversely on their cases. ${ }^{112}$

109. It is difficult to say how long an "insulation" period is needed, but if scrutiny stopped at the time of decision or very shortly after, it would appear that a delayed payment would be a nearly flawless device available to all.

110. The problem of dealing with contributions following favorable actions would be as diffcult to remedy under a judicial scheme.

111. Even in the least complex hypothetical case of one developer contributing to a fund along with other parties who are totally disinterested in the context of later quasi-judicial action, the contribution could be conceptualized in several different ways. If the developer gave $\$ 500$ out of a total fund of $\$ 1,000$, and if four candidates each received $\$ 250$ contributions from the fund, should the developer be considered the $100 \%$ source for two of the four contributions or a $50 \%$ donor to all four? If the developer gives to more than one fund, or if the fund involves multiple interested parties, determining when a contribution becomes an indicia of improper or possible improper influence will require either rigid statutory treatment-likely to be evaded without much difficulty-or flexible case-by-case analysis-likely to take a heavy toll upon innocent risk-averse contributors.

112. 26 Cal. $3 d$ at 947 n.9, 609 P.2d at 1034 n.9, 164 Cal. Rptr. at 260 n.9. 


\section{CONCLUSION}

To summarize, the legislature, and conceivably the courts, could formulate a narrow disqualification standard that would withstand a first amendment challenge. However, the ability to pass constitutional muster does not ensure that such a standard would be a sound policy. For example, if a disqualification standard applied only in certain welldefined cases and only to contributions greater than $\$ 1,000$, the scheme would likely be constitutional. However, chromic disqualification from certain decisions could prevent the official from implementimg his most strongly held beliefs, and could ultimately tlireaten lis sources of political support, financial or otherwise. Any system that discourages candidates from stating their views would be directly opposed to the objectives espoused in Fairfield. In addition, sucli a scheme would be subject to the myriad methods of evasion described above. ${ }^{113}$

In seeking the best means of dealing with the possibility of corrupt imfluence in the Woodland Hills context, it is important to remember the unique nature of the quasi-judicial decisionmaking. ${ }^{114}$ It is adjudicative im character, determining the rights of the parties to the controversy. For that reason, due process is required and decisions are subject to direct judicial review. These features go far toward ensuring a fair and unbiased hearing. The courts can overturn any decision that is procedurally inadequate or not supported by the record. ${ }^{15}$ At the saine time, quasi-judicial decisionmaking by elected representatives is

113. When evasion takes place, it occurs at the expense of discouraged non-culpable contributors whose participation in the political proccss is diminished in relation to the class of evading contributors.

114. A disqualification standard could not be applied strictly to legislative actions. See, e.g., Anderson v. City of Pleasant Hill, 229 Cal. App. 2d 79, 91, 40 Cal. Rptr. 41, 48 (1st Dist. 1964); Ferris v. City of Alhambra, 189 Cal. App. 2d 517, 525, 11 Cal.Rptr. 475, 479 (2d Dist. 1961); see generally Annot., 70 A.L.R.2d 568 (1960). This is true despite the fact that a legislative action can provide as much of a windfall to an individual as a quasi-judicial proceeding. See, e.g., Schauer v. Miami Beach, 112 So. $2 \mathrm{~d} 838$ (Fla. 1959), in which a legislator stood to gain $\$ 600,000$ from a legislative land use decision. The court refused to inquire into the motive of the legislator.

Under a disqualification scheme that exempted legislative decisions, the fortuity of the label placed on an action or the forum in which it took place might determine whether any scrutiny would be applied. If a party were unable to successfully exert his imfiuence on a quasi-judicial matter, he might be able to obtain the same results from the same body acting in a legislative capacity. For example, if a developer suspected that he would be unable to "buy" a use permit, he could attempt to exert his infiuence at an earlier point in deliberations, such as when the local comprehensive plan is under consideration. This loophole not only defeats the purposes of a disqualification standard in quasi-judicial deliberation; it diffuses public scrutiny by submerging the improper infiuence in the passage of a more general enactment and thereby facilitates undesirable behavior.

115. See St. Joseph Stock Yards Co. v. United States, 298 U.S. 38, 73 (1936) (Brandeis, J., concurring); Comment, Zoning Amendments-The Product of Judicial or Quasi-Judicial Action, 33 OHı ST. L.J. 130, 139-42 (1972). Accord, Fasano v. Board of County Comm'rs, 264 Or. 574, 507 P.2d 23 (1973). 
inherently a political process, for it involves issues that affect the public interest. The courts should grant the quasi-judicial process enough deference to allow for the integration of politics in that process. Unlike traditional adjudication, the quasi-judicial process is not tainted by the appearance of any political influence, but only by the appearance of political influence that is itself tainted.

Since political influences are ordinarily a healthy influence on quasi-judicial decisionmaking of the type in Woodland Hills, the rationale for regulation of the electoral process lies in the elinination of corruption. The solution to the problem of corruption through campaign contributions is a broad-based reform of the system of financing elections, not the use of a legislative or judicial fairness test in reviewing quasi-judicial decisions. Such a systemic problem requires a systemic solution.

If, on the other hand, reformers wish to focus only on quasi-judicial decisionmaking, it would appear that their objection is to the injection of political influence itself into the process, ratlier than to evidence of corruption. Such a mistaken view of the decisionmaking process could as easily support disqualification for the receipt of massive volunteer labor as for a money contribution. The California Supreme Court should have used the Woodland Hills case as an opportunity to emphasize the pohitical nature of the quasi-judicial process and to stress that reliance on a political model invariably involves the negative as well as the positive features of politics.

Edward L. Wolf*

* A.B. 1978, Brown University; third-year student, Boalt Hall School of Law, University of California, Berkeley. 